Discussion

\title{
Finding Ways to Improve Australia's Food Security Situation
}

\section{Quentin Farmar-Bowers}

17 The Grange, East Malvern, Victoria 3145, Australia;

E-Mail: Quentin.farmarbowers@deakin.edu.au; Tel.:+61-432-717-084

Academic Editor: Stephen J. Herbert

Received: 27 February 2015 / Accepted: 27 April 2015 / Published: 27 May 2015

\begin{abstract}
Although Australia exports more than half of its agricultural production, there are food security problems as the current food supply systems in Australia fail to deliver healthy diets to all Australians and fail to protect the natural resources on which they depend. In addition, the food systems create "collateral damage" to the natural environment including biodiversity loss. In coming decades, Australia's food supply systems will be increasingly challenged by resource price inflation and falling yields due to climate change. Government and business are aiming to increase production and agricultural exports. This will increase pressure on agricultural resources and exacerbate "collateral" damage to the environment. The Australian public has an ongoing interest in issues associated with the food systems including the environment, education, health and sustainability. A health-giving diet is essential for a full life and over a life-time people need food security. Currently economy development and social planning is undertaken through the pragmatic application of a set of ideas, such as relying on markets and deregulation, collectively referred to as neoliberalism. This paper contends that the neoliberal approach is not solving the current and developing problems in food security and agriculture more generally and suggests that more emphasis should be given to alternatives approaches. Seven alternatives approaches are suggested that could be used to identify gaps and guide the creation of overarching goals in economic development and social planning to improve food security and secure the other material goods and social arrangements that all Australians require to live full lives. However, changing large systems such as those involved in food supply is difficult because vested interests in the existing arrangements make the current systems resilient to change. There are a range of leverage points that have differing abilities to change systems. The paper points out that goals and information flows are good leverage points and suggests establishing overarching goals for the systems relevant to food and restructuring the flow of information about these systems will help reform the food supply systems in Australia.
\end{abstract}


Keywords: agriculture; Australia; diet; food security; natural resources; system change

\section{Introduction}

Australia is a continent comparable in size to the contiguous states of the United States but it is principally dry land with only the eastern seaboard and south-west Western Australia supporting arable farming. Despite this, Australia exports more than half of its agricultural production. This might give the impression that Australians are food secure and that agricultural production is sustainable; this is not the case. Australia's commercial food supply and agricultural systems have a negative impact on some people through, for example, poor diet leading to ill health, (an intra-generational equity issue) and have a negative impact on ecosystems through, for example, land and water degradation and biodiversity loss (an inter-generational equity issue).

These negative impacts are likely to be exacerbated by population growth which is predicted to double in sixty years [1], by increasing economic inequity and by the growing impacts of climate change; including changes to rainfall, with more heatwaves and greater storm intensities [2-4].

Reducing the negative impacts of the domestic food supply systems and agriculture more generally is the collective responsibility of the Australian Commonwealth and State governments and the industries concerned. This collective responsibility would be effectively discharged if these organisations collaborate on the development and implementation of joint goals and work from the perspective of the whole system. It is unlikely that credible long-term solution can be found by dealing with issues independently. It is also unlikely that the current approach to economic development and social planning that encourages reliance on markets and deregulation referred to as neoliberalism will be able to solve the food security issues.

The next five sections of this paper outline the issues and failings involved in the food systems in Australia. Section 7 concerns how these issues are being addressed and provides a very brief outline of neoliberalism; the approach being taken to manage these issues over the last decades. Section 8 asks the rhetorical question "do the systems related to food need to change" and goes on to outline seven alternatives approaches to neoliberalism that could be used to identify how the systems related to food ought to change. These approaches are: (1) human rights; (2) national securities; (3) human needs; (4) authentic happiness; (5) capabilities; (6) sustainable development; and (7) environmental ethics. Section 9 outlines ways of changing systems and suggests developing overarching goals and changing the flow of information about the systems related to food security. Section 10 is the conclusions.

\section{Current Issues for Consumers in the Commercial Food Supply System}

Although about half of surveyed Australian households grow some of their own food [5,6] the vast majority of Australians depend on the commercial food supply systems. The ability of families to eat well is thus substantially related to family income. About 5\% of Australian families suffer food insecurity [7,8] and many suffer diet-related health problems through malnourishment [9], including those related to obesity [10-13] and diabetes [14]. In 2011-2012, 63\% of Australian adults and 25\% of children were classified as overweight or obese [15]. "Unfortunately our diet has changed pretty 
dramatically over 30 years. The composition [of] what we're eating has changed, the really high levels of sugar and fat in our food." [16].

There is evidence that some sectors, such as older Australians [17,18], Aboriginal and Torres Strait Islander people, rural and remote Australians [19] and Australians with low household incomes are more at risk than others. For instance, Ward et al. [20] indicated that low-income families in Adelaide would have to spend about $30 \%$ of household income on eating healthily whereas high-income households needed to spend about 10\%. Barosh et al. [21] studied the inequity in western Sydney in purchasing a health and sustainable diet (H\&S diet) and noted that "The most disadvantaged groups in the region, both at the neighbourhood and household level, experience the greatest inequality in affordability of the H \& S diet."

There are long-term consequences for not eating well, notably for young children [22]. Poor diet is currently implicated in over half of all deaths in Australia [23]. Mathers et al. [24] in 1999 noted that "the most disadvantaged $20 \%$ of Australians have a mortality burden that is $35 \%$ higher than that for the least disadvantaged 20\%". The total direct cost for overweight and obesity in 2005 was \$21 billion with estimated indirect costs of $\$ 35.6$ billion per year, resulting in an overall total annual cost of $\$ 56.6$ billion [25].

This health situation is mirrored in other developed countries [26]. Although obesity occurs at every socio-economic level in society, Drewnowski and Darmon [27] found that "Highest rates of obesity and diabetes in the United States are found among the lower-income groups" and Levine [28] noted that obesity tracks poverty in the USA. The situation in Australia may be similar as Burns [29] noted a relationship between obesity and poverty. Siahpush et al. [30] found that prolonged financial stress was a predictor of obesity in Australia. The Australian health survey data show that more adult women living in areas of most dis-advantage were overweight or obese (63.8\%) compared with women living in areas of least disadvantage (47.7\%). This difference was not seen in data for men [11]. While the causes of the relationship between poverty and unhealthy diet are not clear it would seem that the relative high cost of a healthy diet to income (as suggested by the work of Ward et al. [20]) is likely to be a major factor.

\section{Issues of Resource Degradation in Australian Agriculture}

Agricultural development in Australia has long been associated with land and water degradation [31]. About two thirds of agricultural land in Australia is degraded [32]. The problems range from soil loss and salinization to wetland loss, degradation of river systems and biodiversity decline [32,33-38]. Australia has the worse extinction rate for mammals in the world (29 species since European settlement) and more than 1700 species of plants and animals are listed by the Australian Government as being of risk of extinction [39]. Land and water degradation damage agricultural productivity and also result in "collateral" damage to ecosystems services through reduced functionality of ecosystems and biodiversity loss, including in associated marine areas [40,41].

While some natural resource management issues are within the capacity of individual landholders to deal with, many, perhaps most issues are related to the operation of larger systems both social systems and ecological systems, very often in tandem. For example, social systems have promoted the development of irrigation schemes in Australia which have led to the degradation of river systems such as the 
Murray-Darling system in eastern Australia [42]. This case demonstrates the social and environmental complexity of repairing this major system as a consequence of agricultural development and restoring productivity that will take decades and is likely to require perpetual large scale adjustments as well as individual landholder adaptation [43].

\section{Future Issues}

In addition to the continuation of current issues, increasing demand from the growing Australian population for agricultural products and competition for resources used in agriculture (such as land and water) and climate change will exacerbate these existing problems and introduce new problems.

The income poverty rate (below 60\% of median income) in Australia has been consistently around $21 \%$ in the 2001-2010 decade. A capability approach based on Sen's capabilities approach, [44] indicated that marginal and deep social exclusion rates were about $25 \%$ in 2010 up a little from the decade low point in 2008 [45]. To some degree, the rate of poverty is related to the level of government support payments available $[46,47]$. There seems to be no progress on poverty reduction in the first decade of this century. This is a strong indication that the food issues related to poverty will continue.

The impact of climate change on agriculture is complex and likely to vary from year to year. Overall the physical production is likely to be reduced because of increasing severity of droughts, heatwaves, storms and changes in the pattern of rainfall (rainfall is likely to be less in much of Australia) [48-51]. Agriculture in other parts of the world is also impacted in similar ways [52].

Climate change will not only reduce the harvest from agriculture but policies to mitigate climate change must, in the long-term, be aimed at reducing the greenhouse gas pollution from agricultural production. This is because about $15 \%$ of greenhouse gas production in Australia is estimated to come from agricultural activities (enteric fermentation $65.1 \%$, agricultural soils $17.8 \%$, prescribed burning of savannahs $12.3 \%$ and manure management 3.9\%) [53,54]. Mitigation policies must also reduce the greenhouse gases involved in the resources used in agriculture especially nitrogen fertilizers and fossil fuels and in the production of machinery and equipment used in agriculture and in the manufacturing and retail aspects of the food supply chains.

The current response to climate change in Australian agriculture is principally adaptation; incremental but also transformative change is being discussed [55]. There are moves by the current Australian government from 2013 onwards, to encourage carbon farming [56] to sequester carbon in soils and vegetation as a principal mitigation measure for climate change as part of their emissions reduction fund [57]. A review in 2013 [58] indicated that the potential of improved agricultural management practices to store carbon in soils was limited to the surface $10 \mathrm{~cm}$ of soil and diminished with time. They found that none of the carbon storage practices were financially attractive under Australia's Carbon Farming Initiative. The carbon farming initiative is now part of the emissions reduction fund.

Australian agriculture depends on oil and therefore production is vulnerable to future oil shocks and oil price rises [59-61]. Agricultural production depends on resource inputs such as irrigation water which is already overcommitted [62], phosphate and nitrogen fertilizers [63] and land. It is likely that prices for phosphates will rises because of increasing demand and supply limitation $[64,65]$. The price of nitrogen fertilizers is dependent on the cost of natural gas which has seen significant price fluctuations 
in recent times. It is possible that nitrogen fertilizer prices may stabilise with increasing gas availability and proposed increased manufacturing capacity [66,67].

Land is being lost to agricultural production through land degradation, such as salinity and erosion, but also through city expansion into peri-urban areas [68] and coal seam gas and mining [69]. The outcome of price rises in agricultural inputs, coupled with increasing domestic demand from Australia's rapidly growing population [1] and exports is likely to lead to food price inflation which will have a negative impact on the affordability of a healthy diet for Australians.

Australia's production of agricultural commodities is much greater than the demand from its population of 23 million, allowing Australia to export over half of the physical production of agriculture [70,71]. There are claims (which seem exaggerated) that Australian agriculture feeds about 60 million people world-wide [72]. Business and government want to expand exports further by increasing agricultural production to take advantage of the international demand for food from a growing middle class especially in Asia. The previous Australian Government; The Labor Rudd/Gillard Government 2007-2013, supported an increase in agricultural production and exports setting out their ideas in a National Food Plan [73,74]. The National Food Plan is no longer government policy but the idea of agricultural expansion is still supported. A controversial aspect of agricultural expansion is the proposed development of a "food bowl" in northern Australia [75-77] that has long been held as infeasible [78,79]. Expanding agricultural production (a proposed doubling) will greatly exacerbate the problems of "collateral" environmental damage [80], especially when farming moves into more marginal production areas and increases its use of resources, such as water, fertilisers and fuels.

\section{Public Interests}

The topics that catch and sustain the interest of the Australian public are the ones likely to receive political attention in the longer term. The Australian public's growing interest in food security and sovereignty $[81,82]$.is not spawned by a single issue.

Current issues of public concern around food and diet can be grouped roughly under four headings: consumption, production, environmental and control issues.

Consumption issues include: diet-related health problems, social inequities, poverty, poor diets (especially for children), urbanisation and food deserts, population growth, food insecurity, food imports, making ends meet, ageing population, food waste, food contamination and food safety, premature deaths of Indigenous Australians, GM foods, food quality, food labelling, and food literacy.

Production issues include: vulnerability of production to climate change (droughts, floods, storms and heat waves), oil price rises (e.g., peak oil), fertiliser price rises (e.g., peak phosphate), land and water degradation and pollution, declining growth in agricultural productivity, over-fishing, loss of agricultural resources (land and water) to urbanisation and mining, biofuel production, aquifer pollution from coal seam gas production [83], over allocation of irrigation resources [84], static agricultural research budget, animal welfare, live animal exports, loss of the family farm, the exodus of your people from agriculture coupled with a low turnout of agricultural graduates.

Environmental issues include: river health, biodiversity loss, loss of forests and natural areas, loss of wetlands, by-catch in wild fisheries [85], damage to coral reefs and marine areas [86] and greenhouse gas production. 
Control issues include: foreign ownership of agricultural land and water resources, foreign control of agribusinesses, super-trawlers, globalisation (with the increasing influence of international markets and the increasing power of multinational agribusinesses), supermarket control of food chains, and food providence information. Farmar-Bowers et al. [87] provides an overview of food security in Australia.

The public's concern and mistrust around these issues exists for a range of reasons. There is confusion in the general public about what really constitutes a health providing diet $[88,89]$. The increasing (physical and emotional) distance between farmers and urban consumers leads to a poor general appreciation of where food comes from and what foods might contain [90]. The nature of property rights and industrial agricultural production methods with a focus on profits suggest that producers have low levels of obligations to neighbours including consumers and the natural environment [91]. Industrial agricultural production methods used in Australia may not guarantee food security [92,93]. The sustainability of modern agricultural production is in question in Australia and internationally especially as intensification is likely to lead to a tradeoff between production and more environmental damage [94]. The level of relative poverty in Australia [46], especially among children, contrasts with traditional Australian values of mateship and empathy $[95,96]$. There is also concern in regard to the political influence of the super-rich and large corporations (including the market dominance of the super-market chains) in promoting their own affairs. Seemingly, governments have an economic focus on facilitating increased agricultural production for export with less concern about social and environmental issues at home [97]. There is also concern that the Australian government is not taking climate change seriously as it has dropped nearly all the existing arrangements for climate change mitigation in its first term [98].

\section{How These Failing in the Food System Relate to Preferred Outcomes}

The Australia food system seems to be failing on two counts: (1) in its ability to provide a healthy diet for all Australians; and (2) in its ability to sustain natural resources and protect biodiversity. In addition, it does not seem to be gearing up to deal with the changes that the future is known to bring, especially climate change, population growth and the increasing range of public concerns. Other things being equal, the Australian public would probably prefer to have heathy diets, produced in a way that sustains natural resources, maintains biodiversity and have agriculture and food systems able to copy with coming change.

Healthy diets: Ensuring Australia has a well-nourished population should be seen as an internationally accepted moral obligation and human right within the International Covenant on Economic, Social and Cultural Rights (ICESCR) [99] and also an economic necessity. Roetter and Van Keulen [100] noted that: "The ultimate aim....[of]....food security is to arrive at a healthy and well-nourished population that can take on, to the maximum of its capacities, the development of its own community, area or country". The Australian health ministers accepted that "Improving Australians' diets therefore has (sic) the potential to cut health care costs and improve quality of life" [101]. Although the costs aspects are important, they should be secondary or an additional reason for ensuring people have access to a health giving diet. Issues about health giving diets are reviewed by Katz and Meller [88].

Sustain natural resources: Maintaining current levels of production and moving towards sustainability depend inter alia on: (1) re-developing agriculture (and fisheries) in ways that conserves the natural resources on which production depends (e.g., soil and water quality and fish habitat and stocks); 
(2) reducing agriculture's dependence on fossil fuels, Haber-Bosch nitrogen fertilizer and resources such as mined rock phosphate [102]; (3) reducing the carbon foot-print of the food systems; and (4) improving the control of pests and diseases and biosecurity. By protecting productivity, natural resource conservation has significant prudential value for the future nutrition of Australians and the agricultural economy [103]. Food and agricultural production needs to be carried out within planetary boundaries. This implies the need for considerable change in production methods and resource use [104].

Sustain biodiversity: Natural areas and native biodiversity in Australia has long been valued domestically and internationally. For example, in 2000, Australia was identified as one of 17 mega-diverse countries by the World Conservation Monitoring Centre. In 1993 Australia ratified the 1992 Convention on Biological Diversity and developed a national reserve system project. Australia is periodically adding reserves to the system. An important aspect of conservation is working to reduce agriculture's impact on the natural environment [105] and increase private conservation efforts [106]. In addition to Australia's international legal obligations, the natural environment is accepted by Australian society as having economic, social, cultural and national prestige values. The "collateral damage" to the natural environment from existing agricultural development continues and the pressure for expansion of commercial agriculture with increased resource use is substantial.

Overcoming resource and climate change problems: Australian agriculture is adaptable, notably in regard to weather variability, and there is scope for further adaptation [107,108]. However, there is a limit to adaptation and climate change is likely to lead to declining agricultural yields. Increasing resource costs will lead to higher product prices. These costs may be passed on easily to high value overseas markets but higher food prices may reduce the ability of Australians to purchase healthy diets. The option of selling overseas will tend to move Australian domestic food prices upwards to export parity. The proposed expansion of production is very likely to lead to an increased rate of damage to natural resources and biodiversity.

\section{Will These Failings Lead to New Government Policies and Programs?}

How important these failings are viewed by government now and in future and whether they lead to goal setting and policy development will depend on the political ideas in vogue at the time. Historically, recognition of their political importance has led to government action. For example, the social security and welfare benefits systems [109], help low income Australians buy food; the public health system [110], is paying for ameliorating some of the illnesses due to poor diet; government programs such as "Caring for our Country" [111], is making a contribution towards the restoration of land and water degraded by agricultural production and the national reserve system and environmental protection programs are funding initiatives to reduce agriculture's collateral damage to the environment [112]. Currently the Australian Government proposes a winding back of aspects of these programs, such as reducing or delaying welfare payments [113], introducing medical co-payments [114] and reducing action on climate change and environmental issues [115].

Resolution of the remaining issues is left to private citizens such as landholders for biodiversity conservation on private land, and non-government organisations, such as the Salvation Army, Food Bank Australia, Conservation Volunteers and commercial businesses through their corporate social responsibility programs. 
In the last 30 years, neoliberal ideas [116,117] have become more dominant in all Australian governments' approach to public policy. Neoliberal ideas put faith in markets and the maintenance of the value of money (via interest rate control) to provide for the advancement of human welfare. Application of these ideas has led to deregulation, privatization, establishment of markets in many new areas, smaller government, the withdrawn of the state from the provision of many social programs and the acceptance of personal responsibility for events often even in the face of clear system failures. The practical application of neoliberal ideas has varied from the original theory across time and between countries making a clear definition of neoliberalism difficult. Despite this, neoliberal ideas have become the "norm" for thinking about problems and solutions in Australian society. Consequently intra-generational inequity (e.g., income inequity) and inter-generational inequity (e.g., low level of climate change mitigation) are considered to be "natural" with less urgency for ameliorative action from government as it is assumed that solutions will come from the "market".

The move towards embracing neoliberal ideas has led to the reduced relative spending power of lower wage earners and welfare recipients [118] and has consequences in health outcomes [119] Although increasing equity appears to be beneficial for social outcomes [120], Whiteford [121] suggested that "Rising inequality and rising prosperity are therefore characteristic of Australia's experience over recent decades". And "while all income groups have benefited from increases in real incomes, the benefits have gone mainly to the better off'. Like Australia, inequity has increased in most OECD countries in the last 30 years [122,123]. Harvey [124] maintains that in a sense neoliberalism is about the concentration of wealth and power in the hands of a concentrated part of society and this power facilitates the perpetuation of policies that maintain this situation. Certainly, the neoliberal ideas in play in Australia have facilitated expansion of big business and wealth at the top of the social scale. They also result in food security, natural resources protection and biodiversity maintenance, being low on the Australian Government's agenda although there is lobbying by civil society and minor political parties [125] and a number of local government councils have food security plans and programs [126]. The Australian Government issued a green paper in 2014 on agricultural competitiveness and will release a white paper in late 2015 . The green paper notes that "The Australian Government's agricultural policy is driven by one key objective: to achieve a better return at the farm gate to ensure a sustainable and competitive Australian agriculture sector" [127]. The Australian Government has nine policy principles related to Agriculture which are set out in their green paper on Agricultural Competitiveness; the ninth principle is "Maintains access for all Australians to high-quality and affordable fresh food" [127]. The green paper relies on neoliberal ideas by suggesting the current issues of food insecurity in Australia are problems the individual should deal with. "Australia has a high level of food security due to our income level and trade surplus in food. Australia is ranked the 15th most food secure country on the assessment of 109 nations by the Economist Intelligence Unit [128]. Pockets of food insecurity for some individuals and communities in Australia remain due to low income or remoteness." [127].

Issues relating to food/health, natural resources and biodiversity seem important for the future. If we rely on neoliberal ideas then it would seem that we are passing responsibilities for "fixing" the failings of the food system listed in Section 6 above to the "market". There is nothing wrong with this if this approach is effective but evidence suggests otherwise. As a democracy, ideas about these vital issues and how to proceed should be on the public agenda for "good sense" debate. The following three questions are suggested as "debate starters": 
- Do the systems related to food need to change? And if so,

- What levers might be useful in making the changes?'

- How can the people and organisations use the levers to make changes?'

\section{Finding out "What Ought to be": Is System Change Needed?}

This section addresses the first of the three questions above: Do the systems related to food need to change? The following section (Section 9) addresses the other two questions.

From a neoliberal perspective "what ought to be" is set out in the Federal government's green paper mentioned in above; basically better returns to agriculture (higher profits). The green paper is a step in a public discussion process. High on the requirements for a "good sense" public discussion is reliable and full information about the systems involved and about the criteria needed to evaluate the systems. Although there is information about the food systems and closely related systems such as employment, education, health, welfare, natural resources, information is needed on how the systems interact. However, just knowing about the systems involved and their impacts on people and the environment is not adequate; these has to be a moral objective or ethical systems to evaluate this information to identify gaps between current reality and "what ought to be". This implies that the most pressing issue now is deciding what moral or ethical systems should we use to decide "what ought to be" so we can identify the gaps that exist between "what ought to be" and the current situation. Should we rely on neoliberal ideas or are there other approaches such as moral objectives or ethical systems we can use. Once we have decided on an approach we can identify gaps and hence what overarching goals we should be develop to close these gaps. Once we have overarching goals, it may be possible to determine a suite of secondary goals for individual issues and develop programs to implement the goals. Developing and using appropriate goals is vital as goals help to direct and energise effort, encourage persistence, and also help people to use and develop skills and knowledge [129].

Many alternative ideas to neoliberalism exist that could be used to identified the gaps between "what is" and "what ought to be". Seven alternative sets of ideas from which we could identify gaps and hence develop overarching goals are considered in this paper. The alternative ideas considered are: (1) human rights; (2) national securities; (3) human needs; (4) authentic happiness; (5) capabilities; (6) sustainable development; and (7) environmental ethics. The distinction between these ideas is not always sharp and there are ways of using ideas together to determine gaps and overarching goals.

Human rights: The Australian Government ratified the 1966 International Covenant on Economic, Social and Cultural Rights in 1975. Article 11 Sections 1 and 2a and 2b, refers to food "right of everyone to an adequate standard of living for himself and his family, including adequate food, clothing and housing, and to the continuous improvement of living conditions" and Article 12 refers to health "the right of everyone to the enjoyment of the highest attainable standard of physical and mental health" [130]. Adequate food is thus a human right. As a consequence of the commitments made in 2011 during Australia's Universal Periodic Review at the United Nations and Australia's Human Rights Framework 2010, the government produced its third National Human Rights Action Plan in 2012 [131]. The plan addresses poverty as one of the 19 topics discussed which included mention of the "Food for All Tasmanians: A Food Security Strategy 2012" [132] developed as advice to the Tasmanian Government. The Action Plan also included references to health for Indigenous Australians in the 
"Closing the Gap" program, and national food security was mentioned in terms of climate change programs. While the Tasmanian advisory strategy and the work with Indigenous Australians represent an important appreciation of the need for change, it seems that this approach to "human rights" is not proving to be the catalyst for substantial and rapid change in Australia.

National securities: Most countries have some form of national security agenda. The Australian National Security Statement [133] sets out five national security objectives. They concern; border integrity, political sovereignty, protecting Australia's national interests and promoting global stability in Australia's interests. The third objective of the five national security objectives is: "preserving a cohesive and resilient society and strong economy". As a flow on from this third national security objective, the Australian Government has developed a "Critical Infrastructure Resilience Strategy" which identifies seven critical sectors within the Australian economy that must not fail if this third national security objective is to be met [134]. The food chain is one of the seven critical infrastructures that must be maintained. "The aim of this Strategy is the continued operation of critical infrastructure in the face of all hazards, as this critical infrastructure supports Australia's national defense and national security, and underpins our economic prosperity and social wellbeing. More resilient critical infrastructure will also help to achieve the continued provision of essential services to the community" [134]. The other sectors that must be maintained are; energy, water, communications, transport, health and banking.

Although the food chain is only one of the seven critical infrastructures identified in the Critical Infrastructure Resilience Strategy, it is easy to see that the other sectors; energy, water, communication and transports, as well has having their own values, are essential for maintaining food supply chains, and food, in the sense of good nutrition, is essential for health (the remaining critical infrastructure objective). The critical infrastructure approach is relevant for government's planning for crises such as cyclones and acute financial problems that might occur in groups of people (such as farmers). Citizens, as well as government, would want these "infrastructures" to be maintained in a crisis but citizens probably want these "infrastructures" to be satisfied throughout our lives. So while the securities approach may be useful for crisis evaluation, in its current form, it may not provide useful criteria for evaluating ongoing day to day issues such as healthy diets and protection of natural resources for food production. In contrast to the situation with food, the "strong economy" aspect in the third objective of national security agenda is a central and daily focus of government, quite apart from its security aspect.

Human needs: Human needs were given a central position in the Brundtland report on sustainable development [135]. Max-Neef et al. [136] listed nine fundamental human needs as: subsistence, protection, affection, understanding, participation, leisure, creation, identity and freedom. Max-Neef's notion is that people or societies are "poor" when one or more of these needs are not met. "Security" is about ensuring each of these needs will always be fulfilled in the future. Most of these needs are psychological, but to achieve them we have to use materials and establish social arrangements and processes. For example, "leisure" requires places for recreation as well as the social acceptance of "free time".

Instead of trade-offs between needs, the "needs approach" asks us to seek synergies so that one action can secure as many human needs as possible. A balance is required in policy and within the functioning of society to avoid the situation in which the provision of a specific need hinders the provision of people's other needs. For example, too much "protection" could mean a police state (loss of freedom); too much "subsistence" in the form of high calorie food could mean obesity and ill health (loss of protection). 
"Freedom" is an especially difficult need to balance; e.g., do we sanction freedom to burn fossil fuels or freedom to enjoy clean air and a stable climate.

In terms of psychological needs, "Self-determination Theory" postulates that social conditions can either facilitate or forestall the satisfaction of three innate psychological needs; competence, autonomy and relatedness. Self-determination theory holds that satisfaction of these needs enhances self-motivation and mental health, conversely, not meeting these needs leads to lower motivation and reduced well-being [137,138]. In other words, people need to have the feeling of competence (based on real rather than imagined competence), to be able to make and implement their own decisions and have friendships to be mentally healthy and actively motivated. Motivation and mental health impact people's activities in all areas of their lives. In terms of psychological well-being self-determination theory may provide useful criteria along with Max-Neef's fundamental human needs to evaluate the current situation to identify gaps and devise overarching goals.

Authentic Happiness: Perhaps "authentic happiness" would also provide a useful criterion for evaluating food systems as authentic happiness has a central role in people's well-being. But it has to be "authentic", that is real and not the consequence of mis-information; "happiness has no prudential payoff unless it is fully informed...." [139]. One is not going to be authentically happy if suffering a terminal illness as a consequence of an unhealthy diet. Haybron [140] supports this notion and proposes that welfare centres on self-fulfilment, part of which is authentic happiness. Haybron notes that: "A full-blooded account of welfare would likely incorporate goods other than happiness, depending on how we view our natures. Obviously important in this regard.....is a person's identity. And it is highly plausible that self-fulfilment will involve, not just being happy, but success as well in relation to those commitments that define who we are and lend meaning to our lives.....welfare consists partly .....on how things go with respect to the commitments that shape one's identify......we should consider incorporating identity-related fulfilments into an account of well-being as part of fulfilment" [140]. Haybron used the example of the loss of a spouse as a commitment but probably there are a wide range of commitments that would be "identity-related" such as having well-nourished children or conserving native biodiversity on your farm. Haybron [140] points out that well-being (and the authentic happiness theory) is an evaluative concept by asking if people are happy with their life (or with their well-being). Consequently we could use it to evaluate the current systems around food to determine their ability to deliver authentic happiness or not. The United Nations' World Happiness Reports provide a practical example of applying happiness as a evaluative criterion [141].

Capabilities: the capabilities approach asks the question: What are people actually able to do and to be? The answer is the set of capabilities, or real opportunities, that a person has and is able to count on in future (capability security). The "capabilities approach" is the framework used in the Human Development Reports published by the United Nations Development Programme (UNDP) and is used in many state and regional development reports. "Capabilities are important human entitlements, inherent in the idea of basic social justice, and can be viewed as one species of a human rights approach" [142]. Nussbaum [143] has proposed a tentative set of ten central human capabilities that provide a basic set for social justice. Their fulfilment requires affirmative action and government support for their creation and maintenance. They are: (1) Life, living a normal length; (2) Bodily health; (3) Bodily integrity; free from violence; (4) Senses, imagination, and thought, ranging from education, religion to freedom of expression; (5) Emotions, being able to express emotions; (6) Practical reason, being able to plan one's life; 
(7) Affiliation, (A) social interaction, (B) to have social respect; (8) Other species, have concern for the world of nature; (9) Play, enjoy recreational activities; (10) Control over one's Environment, (A) political, (B) material. Nussbaum [142] has the view that governments have work to do in regards to capabilities: "If a capability really belongs on the list (or, if a given human right really belongs in a list of human rights), then governments have the obligation to protect and secure it, using law and public policy to achieve this end".

In discussing the capability approach and sustainability Sen [144] suggested that "A fuller concept of sustainability has to aim at sustaining human freedoms, rather than only at our ability to fulfil our felt needs." Sen suggested that determining needs (perhaps done by experts) would reduce freedom to choose; "There is a big issue of individual choice here. There is also a related "social choice" problem, in determining the priorities between different kinds of freedoms, or, for that matter, even in the identification of different types of needs and the priorities between them" [144]. He holds that prioritised (crucial) freedoms are those that people have reason to value. Crucial freedoms may include: "such liberties as freedom from hunger, from illiteracy, from avoidable ill-health, from escapable mortality, as well as the freedom to achieve dignity and respect, among other critical emancipations" [144]. These freedoms require broad based social support programs to become operational. The notion is to give certain freedoms priorities and that such freedoms are not likely to be adapted downwards by deprivation as needs might be (e.g., being destitute but thankful/happy for small mercies). Debate is suggested as the process for identifying what "crucial freedoms" are, and presumably "having reason to value" is the key. It seems that Sen's approach could be used to provide priorities in Nussbaum's list of ten central capabilities in particular cases through debate among the people involved. Debate would allow the people freedom to choose.

Sustainable Development: The definition of sustainable development from the Brundtland report is:

"Sustainable development is development that meets the needs of the present without compromising the ability of future generations to meet their own needs. It contains within it two key concepts:

(1) the concept of "needs", in particular the essential needs of the world's poor, to which overriding priority should be given; and development [152]

(2) the idea of limitations imposed by the state of technology and social organization on the environment's ability to meet present and future needs." [135]

Sustainable development takes a system thinking approach to integrate environmental, social and economic pillars and as such provides a good approach to identifying gaps and developing overarching goals for the food systems. Applying sustainable development ideas has had mixed success in Australia perhaps because the economic pillar, using neoliberalism, has been favoured over the social and environmental pillars [145].

Environmental ethics: Environmental ethics addresses the notion that the future of humanity is linked with the future of the functioning of ecosystems. Maintaining the productive capacity of ecosystems is an important aspect of ensuring the ongoing production of health-giving diets for all people (i.e., natural resource and biodiversity maintenance aspects of agriculture and the food supply systems). In addition to this instrumental value of nature Pelenc et al. [146] points out that many people recognize intrinsic values of nature. Therefore only giving nature an instrumental value for humanity is an underestimation of what many people feel and value in nature. 
Instrumental and intrinsic valuations of nature can provide assessment criteria. For example, Leopold's land ethic, "that something is right when it maintains the integrity, stability and beauty of the biotic community" is relevant [147]; or the eight point platform for deep ecology that sets out the intrinsic value and connectedness of human and nonhuman life and indicates that the flourishing of human life and cultures is compatible with a substantial decrease in human population [148]. The platform raises a basic problem as it asks for a balance between human vital needs and the interests of the rest of nature $[149,150]$ Meyer [151] also highlights the balance between people and nature and suggests that the problem of how much of the Earth's resources should be for humans and how much for other forms of life, may be one of the most important ethical questions of our times. Liu et al. [95] suggest that this issues needs to be on the international agenda for debate.

Which approach is best for evaluating food security? It is likely that any or all of these seven approaches would help governments identify gaps between "what is" and "what ought to be" in terms of food security. Perhaps Max-Neef's nine human needs or Nussbaum ten central human capabilities being more clearly defined might expedite gap analysis and the development of overarching goals but all approaches discussed above could provide assessment criteria to identify gaps and then develop overarching goals for the food systems.

However, in studying these alternative approaches it is obvious that there are more needs, more capabilities, more freedoms, more ecological values or more human rights than those that relate only to the food supply systems. While we want food security we, as a society, also want these other values to be available to us over a life time (and for future generations); they too must be secure implying that we need a number of securities. Food systems can and do modify these other values such as ecological systems, biodiversity and health. So food security is not independent of these other securities but rather they are all integral parts of larger systems. The seven alternative approaches outlines provide people with the opportunity to see food security in the context of the other securities we need in the long term in order to have a flourishing human society. It seems unlikely that neoliberalism with its reliance on markets and concentration of power and wealth provides such opportunity.

We would want to know, for example, if implementing a program or policy would protect biodiversity and protect the integrity of ecosystems. Each of the overarching goal could represent a "security" in that they concern material goods (such as a health-giving diet) or a process (such as access to justice) that people would want to know are available and a "secure feature" of society into the future.

It is clear that the food supply systems ought to change because currently they are not delivering all the needs or freedoms or rights or securities people require and are not protecting nature on which humans depend. That is, the food systems are not sustainable in social and environmental terms. Nor are food systems sustainable in national economic terms because poor diets lead to ill health and a reduced working life.

Substantial change is unlikely to happen any time soon in Australia because vested interests in the current situation have sufficient economic and political power to suppress these ideas. Perhaps another way of viewing this is to note that ideas about needs and securities (such as food security, or ecological security/conservation) have been around for decades yet have not been sufficiently viable politically to lead to substantial change. It may be that the diversity of approaches dissipates intellectual energy away from effective change. Undoubtedly the ideas have made a difference but they have to overcome the very strong vested interests and a persuasive neoliberal turn in politics that has created powerful organisations and people wishing to continue on the current policy trajectories. The deck is stacked against reforming 
the systems related to food in any substantial way as the current commercial approach to food production is part and parcel of the apparently successful current approach to all industrial development [152].

Perhaps climate change and population growth will force change. Hopefully, the necessary changes can be developed through public discourse democratically over the coming years and not come out of crisis as emergency measures.

\section{What Levers Might be Useful in Making the Changes?}

Should we manage to agree on what the changes to the systems ought to be, we must then find levers that will work. While there are no levers that might act as a "silver bullet" to change the systems overnight, some levers may be more effective than others. So this section addresses the two questions: "what levers might be useful in making the changes" and "how can people and organisations use the levers to make changes".

A three steps iterative process is suggested to work out which levers might be the most effective. The first step is to obtain an understanding of what to address the gaps exist between "what is" and "what ought to be".

The second step is to obtain a deeper appreciation of the systems involved and how they behave and interact. The systems involved include more than just the food supply systems. The commercial food supply systems sit within a wider framework of human and ecological systems such that the food systems are part of larger social-ecological systems in which people interact with the world's biophysical landscapes and processes [153]. Causes and solutions for problems in the food systems, such as poor health from poor diets, may exist outside the immediate food supply systems. Poor diet may have its origins in a wide range of factors that are influenced by many other systems. These may include poverty (employment system), lack of nutritional education (education system), and/or lack of access (transport or retail systems). Gunasekera et al. [154] put forward an economic perspective for research on food security within the "human-earth" system. However, an even wider frame may be needed for many long-term issues. People do not want the food system to "fail", so resilience may be a useful idea in food security research $[155,156]$. The notion in resilience is that system failure (losing the things we value that the system produces) might be avoided if we can maintain innovation to transform the system, or parts of it, to keep the benefits coming and the failure point somewhere in the future. Unfortunately there are many systems involved in Australia's domestic food supply problems in addition to the actual food supply chains and this complexity is further enhanced by globalisation as many of the systems are influenced or controlled by systems that operate globally. The global influence may be physical, such as oil or fertilizer supply, or social, such as ideas about economics or conventions on biodiversity and human rights. This makes understanding the operation, interaction and impacts of these systems on the Australian food issues very difficult. To help address the difficulties in understanding globally complex systems Anderies et al. [157] reviewed the key concepts of sustainability, resilience, and robustness. Their aim was to clarify the meaning of these terms and suggest how they can be used in tandem to address the complexities involved in national and global social-ecological systems. A better understanding of how the systems operate will provide the basis for the next step of finding an effective mechanism to resolve Australia's food issues. Information gathered in this second step will facilitate the development of 
overarching goals that are capable of closing the gaps identified in step one; the gaps between "what is" and "what ought to be".

The third step is about finding effective change mechanisms. Meadows [158] listed twelve ways in which to change systems in a declining order of effectiveness (Table 1). She notes that the order in the list is "slippery" because there are exceptions which can move the leverage point up or down the list. The higher the leverage point (the lower the number in this list) the more effective the lever but the more the system will resist change.

Table 1. How to change systems [158].

\begin{tabular}{l}
\hline Parts of Systems \\
\hline 12. Constraints, parameters and numbers (such as subsidies, taxes and standards) \\
11. Size of buffers and other stabilizing stocks relative to their flows \\
10. Structure of material stock and flows (such as transport networks and population \\
age structures) \\
9. Length of delays relative to rate of system change \\
8. Strength of negative feedback loops relative to the impacts they are trying to control \\
7. The gain around driving positive feedback loops \\
6. The structure of information flows (who does and does not have access to what kinds of \\
information) \\
5. The rules of the system (such as incentives, punishments and constraints) \\
4. The power to add, change, evolve or self-organise system structure \\
3. The goals of the system \\
2. The mindset or paradigm out of which the system-its goals, structure, rules, delays and \\
parameters - arises \\
1. The power to transcend paradigms \\
\hline
\end{tabular}

To change the systems in Australia to deal with poor diets, natural resource and biodiversity losses. We should be looking for a lever at a low number, perhaps at six or below in Meadows's list. The first step, mentioned above, was to work out the gaps between "what is" and "what ought to be" and step 2 involved developing overarching goals to address these gaps. Goals come in at No 3 in Meadows' list so implementing these overarching goals aimed at filling the gaps would be very effective. However, developing goals that motivate people to take action may involve considerable iteration and wide consultation with people involved directly in the food systems and in related systems such as health, employment and education (see for guidance: [129]).

Development of renewable energy (e.g., wind and solar) in Australia is a demonstration of the powers of these alternative levers. The fossil fuel electricity generators are able to change the rules of the system (such as changing the electricity tariffs and costs for installing and running renewable grid connected energy). This is lever No. 5. The renewable electricity industry has the goal of climate mitigation, reducing electricity costs and a changed mindset in terms of becoming independent of the multinational fossil fuel electricity companies and providing home grown power. These include a range of levers such as Nos. 6 and 7 but also include No. 2; "people's mindsets". It would seem that renewable electricity industry has the more effective lever at No, 2 if they can apply it by changing enough "mind sets", but the fossil fuel companies have political and financial power [159-162]. 
Having the ability to use a lever (such as No. 2 changing mindsets) and actually applying it, so that a significant proportion of the population develops this mindset, are two different things. In a democratic country like Australia, Meadow's No. 6; The structure of information flows, could be an important lever for changing the systems to ensure the problems of the food supply systems (food security, health, and the maintenance of natural resources and biodiversity) are resolved in a reasonable time period. Arrangements need to be made to ensure that reliable and comprehensive information about the issues flows through authoritative organisations to critical people in leadership positions in ways that will get their attention and influence their decisions. In addition, paying attention to these matters in education would improve the structure of information flows for the longer term [163].

Changing the structure of information flow is a tactic used by government. For example, the current Australian Government tried to reduce the flow of information on climate change in a number of ways; for example, by abolishing the Climate Change Commission that was established by the former government to provide public information on climate change [164] and by trying to keep climate change off the agenda of the G20 heads of government summit help in Brisbane in November 2014 [165]. In the former case the employees established a crowd funded information provider, the Climate Council, and in the second case other world leaders decided to discuss climate change at the summit.

\section{Conclusions}

The food supply systems in Australia fail to deliver healthy diets to all Australians and protect the natural resources on which agricultural production depends. The operation of the systems also creates "collateral damage" to the natural ecosystems including biodiversity loss. The food supply systems and food prices will be challenged by resource price increases and production decline due to climate change. Food prices will be further challenged by increasing domestic demand for food and increasing demand for the resources used in agriculture and by increasing exports to the expanding middle and upper classes mainly in Asia. The expansion of Australian agriculture to increase exports is likely to increase the collateral damage to the environment and have a negative impact on the sustainability of resources used in agriculture. The food supply systems are also nationally economically unsustainable because the poor diets they deliver lead to ill health and a reduced capacity for work.

There is a range of evaluative approaches that could be used to address these issues. The paper briefly discusses seven of these, which are: human rights, national securities, human needs, authentic happiness, capabilities, sustainable development and environmental ethics. These approaches could help to clearly identify the gaps between what currently exists and what ought to exist in the food systems and develop overarching goals to address these gaps. These seven approaches contain powerful ideas and already have had an impact on what happens, but so far they have not been applied in ways that resolve the food issues that exist in Australia's food supply systems. Implementing the overarching goals to close the gaps depends on being able to successfully apply policy levers to change how the systems operate and create more acceptable outcomes. Obtaining and employing effective leverage points for changing the food systems is difficult because change has to overcome resilience in the existing systems coming from economically and politically powerful vested interests. Perhaps changing the structure of information flows would be a feasible leverage point facilitated by Australia's democratic political system. 
The food supply systems ought to facilitate the consumption of a health giving diet for all Australians throughout their lives. However, the seven approached described in this paper identify other "needs", "capabilities" and "rights" as well, such as ecological stability, health and leisure that are important for humanity and ought to be secured for the long-term to enable individuals and societies to flourish. In improving food security in Australia, we ought to opt for policies and programs that deliver a full range of securities synergistically rather than competitively.

The existence and continuation of the problems in the food supply systems in Australia are a black mark against society as options available in Australia, as a wealthy and well-endowed country, are such that these issues could be substantially resolved within a generation.

\section{Acknowledgments}

I would like to thank John Martin for encouraging my interest in food security and Andrew Parratt for his support and my visitor status at Deakin University.

\section{Conflicts of Interest}

The author declares no conflict of interest.

\section{References}

1. ABS. Catalogue 3101.0 - Australian Demographic Statistics, June 2014; Australian Bureau of Statistics: Canberra, ACT, Australia, 2014.

2. BoM. State of the Climate, Bureau of Meteorology and CSIRO, 2014. Available online: http://www.bom.gov.au/state-of-the-climate/documents/state-of-the-climate-2014_low-res.pdf? ref=button (accessed on 26 February 2015).

3. Steffen, W. Quantifying the Impact of Climate Change on Extreme Heat in Australia; Climate Council of Australia Limited: Canberra, ACT, Australia, 2015.

4. Rosenzweig, C.; Elliottb, J.; Deryng, D.; Ruanea, A.C.; Müllere, C.; Arneth, A.; Booteg, K.J.; Folberthh, C.; Glotteri, M.; Khabarovj, N.; et al. Assessing agricultural risks of climate change in the 21 st century in a global gridded crop model inter-comparison. Proc. Natl. Acad. Sci. USA 2014, 111, 3268-3273.

5. Wise, P. Grow Your Own: The Potential Value and Impacts of Residential and Community Food Gardening; The Australia Institute: Canberra, ACT, Australia, 2014.

6. O'Kane, G. What is the real cost of our food? Implications for the environment, society and public health nutrition. Public Health Nutr. 2011, 15, 268-276.

7. Temple, J.B. Severe and moderate forms of food insecurity in Australia: Are they distinguishable? Aust. J. Soc. Issues 2008, 43, 649-668.

8. Coles-Rutishauser, I.; Penm, R. Monitoring food habits and food security: Australia. In 1995-1996. Food and Nutrition Monitoring Unit Working Paper No. 96.3; Australian Institute of Health and Welfare: Canberra, ACT, Australia, 1996. 
9. AIHW. Australia's Health 2010. Australia's Health No. 12. Cat. No. AUS 122. Available online: http://www.aihw.gov.au/WorkArea/DownloadAsset.aspx?id=6442452962 (accessed on 24 March 2012).

10. ABS. Catalogue 4719.0 - Overweight and Obesity in Adults, Australia, 2004-2005; Australian Bureau of Statistics: Canberra, ACT, Australia, 2008.

11. ABS. Catalogue 4338.0-Profiles of Health, Australia, 2011-2013; Australian Bureau of Statistics: Canberra, ACT, Australia, 2013.

12. Haby, M.; Markwick, A. Future Prevalence of Overweight and Obesity in Australian Children and Adolescents, 2005-2025. Available online: http://docs.health.vic.gov.au/docs/doc/768FD9A 0683F9259CA2578EC0081AD6A/\$FILE/future_overweight_prevalence_report.pdf (accessed on 27 August 2013).

13. Zimmet, P.Z.; Phillip, W.; James, T. The unstoppable Australian obesity and diabetes juggernaut. What should politicians do? Med. J. Aust. 2006, 185, 187-188.

14. AIHW. National Indicators for Monitoring Diabetes: Report of the Diabetes Indicators Review Subcommittee of the National Diabetes Data Working Group. Diabetes Series no. 6. Cat. no. CVD 38. Available online: http://www.aihw.gov.au/WorkArea/DownloadAsset.aspx?id=6442455061 (accessed on 20 February 2015).

15. ABS. Catalogue 4364.0.55.001-Australian Health Survey: First Results, 2011-2012; Australian Bureau of Statistics: Canberra, ACT, Australia, 2012.

16. ABC. Australian Obesity Rates Climbing Faster than Anywhere Else in the World, Study Shows. Interviews on News Breakfast Including Professor Rob Moodie. Available online: http://www.abc. net.au/news/2014-05-29/australian-obesity-rates-climbing-fastest-in-the-world/5485724 (accessed on 25 February 2015).

17. Radermacher, H.; Feldman, S.; Bird, S. Food security in older Australians from different cultural backgrounds. J. Nutr. Educ. Behav. 2010, 42, 328-336.

18. Rosier, K. Food Insecurity in Australia: What is It, Who Experiences It and how can Child and Family Services Support Families Experiencing It? Australian Institute of Family Studies, Child and Family Community Group, CAFCA Practice Sheet-August 2011. Available online: https://aifs.gov.au/cfca/sites/default/files/publication-documents/ps9.pdf (accessed on 19 February 2015).

19. AIHW. Australia's Food \& Nutrition 2012. Cat. No. PHE 163; Australian Institute of Health and Welfare: Canberra, ACT, Australia, 2012.

20. Ward, P.R.; Verity, F.; Carter, P.; Tsourtos, G.; Coveney, J.; Wong, K.C. Food Stress in Adelaide: The relationship between low income and the affordability of healthy food. J. Environ. Public Health 2013, 2013, 1-10.

21. Barosh, L.; Friel, S.; Engelhardt, K.; Chan, L. The cost of a healthy and sustainable diet—Who can afford it? Aust. N. Zeal. J. Public Health 2014, 38, 7-12.

22. The First Thousand Days. Available online: http://www.thousanddays.org (accessed on 21 March 2015). 
23. NHMRC. Australian Dietary Guidelines Incorporating the Australian Guide to Healthy Eating, Providing the Scientific Evidence for Healthier Australian Diets, Draft for Public Consultation, December 2011. National Health and Medical Research Council. Available online: https://www. eatforhealth.gov.au/sites/default/files/files/public_consultation/n55_draft_australian_dietary_guid elines_consultation_111212.pdf (accessed on 10 March 2012).

24. Mathers, C.; Vos, T.; Stevenson, C. The Burden of Disease and Injury in Australia-Summary Report; Australian Institute of Health and Welfare: Canberra, ACT, Australia, 1999.

25. Colagiuri, S.; Lee, C.M.Y.; Colagiuri, R.; Magliano, D.; Shaw, J.E.; Zimmet P.Z.; Caterson, I.D. The cost of overweight and obesity in Australia. Med. J. Aust. 2010, 192, 260-264.

26. Marmot, M.; Wilkinson, R. Social Determinants of Health; Marmot, M., Wilkinson, R., Eds.; Oxford University Press: Oxford, UK, 2005.

27. Drewnowski, A.; Darmon, N. The economics of obesity: Dietary energy density and energy cost. Am. J. Clin. Nutr. 2005, 82, 265S-273S.

28. Levine, J.A. Poverty and obesity in the U.S. Diabetes 2011, 60, 2667-2668.

29. Burns, C. A Review of the Literature Describing the Link between Poverty, Food Insecurity and Obesity with Specific Reference to Australia. Available online: http://secondbite.org/sites/ default/files/A_review_of_the_literature_describing_the_link_between_poverty_food_insecurity _and_obesity_w.pdf (accessed on 2 October 2013).

30. Siahpush, M.; Huang, T.T.K.; Sikora, A.; Tibbits, M.; Shaikh, R.A.; Singh, G.K. Prolonged financial stress predicts subsequent obesity: Results from a prospective study of an Australian national sample. Obesity 2014, 22, 616-621.

31. Gretton, P.; Salma, U. Land Degradation and the Australian Agricultural Industry, Staff Information Paper. Available online: http://www.pc.gov.au/research/completed/land-degradation/ landdegr.pdf (accessed on 20 February 2015).

32. Lumb, M. Land Degradation Facts Sheet, the Australian Collaboration. Available online: http://www.australiancollaboration.com.au/pdf/FactSheets/Land-degradation-FactSheet.pdf (accessed on 23 March 2015).

33. ABS. Australia's Biodiversity. In 1301.0-Year Book Australia, 2009-2010; Australian Bureau of Statistics: Canberra, ACT, Australia, 2010.

34. Bradshaw, C.J.A. Little left to lose: Deforestation and forest degradation in Australia since European colonization. J. Plant Ecol. 2012, 5, 109-120.

35. Chappell, M.J.; LaValle, L.A. Food security and biodiversity: Can we have both? An agroecological analysis. Agric. Hum. Values 2011, 28, 3-26.

36. EA. Salinity and Water Quality; Department of Sustainability, Environment, Water, Population and Communities: Canberra, ACT, Australia, 2012.

37. SoE. Australia State of the Environment 2011-In Brief; State of the Environment 2011 Committee: Canberra, ACT, Australia, 2011.

38. Whittington, J.; Liston, P. Australia's Rivers. 1301.0-Year Book Australia; Bureau of Statistics: Canberra, ACT, Australia, 2003.

39. Australian Wildlife Conservancy. Available online: http://www.australianwildlife.org/wildlife. aspx (accessed on 21 March 2015). 
40. Cardinale, B.J.; Duffy, E.J.; Gonzalez, A.; Hooper, D.U.; Perrings, C.; Venail, P.; Narwani, A.; Mace, G.M.; Tilman, D.; Wardle, D.A.; et al. Biodiversity loss and its impact on humanity. Nature 2012, 486, 59-67.

41. Kroon, F.J.; Schaffelke, B.; Bartley, R. Informing policy to protect coastal coral reefs: Insight from a global review of reducing agricultural pollution to coastal ecosystems. Mar. Pollut. Bull. 2014, $85,33-41$.

42. Holland, J.E.; Luck, G.W.; Finlayson, C.M. Threats to food production and water quality in the Murray-Darling Basin of Australia. Ecosyst. Serv. 2015, 12, 55-70.

43. CoA. Basin Plan 2012; Commonwealth of Australia: Canberra, ACT, Australia, 2012.

44. Robeyns, I. The Capability Approach, the Stanford Encyclopedia of Philosophy (Summer 2011 Edition) 2011. Available online: http://plato.stanford.edu/entries/capability-approach/ (accessed on 9 October 2013).

45. Azpitarte, F. Social Exclusion Monitor Bulletin December 2012, Research Bulletin. Brotherhood of St Laurence and the Melbourne Institute of Applied Economic and Social Research 2012. Available online: http://www.bsl.org.au/pdfs/Azpitarte_Social_exclusion_monitor_bulletin_ Dec2012.pdf (accessed on 2 October 2013).

46. Australian Council of Social Service. Poverty in Australia: ACOSS Paper 194 (Updated March 2013); Australian Council of Social Service: Strawberry Hills, NSW, Australia, 2012. Available online: http://www.acoss.org.au/uploads/ACOSS\%20Poverty\%20Report\%202012_Final.pdf (accessed on 6 October 2013).

47. Goldie, C. For a Real New Start, Stop Miring People in Poverty; Australian Council of Social Service (ACOSS): Redfern, NSW, Australia, 2013.

48. Cleugh, H.; Smith, M.S.; Battaglia, M.; Graham, P. Climate Change: Science and Solutions for Australia; Cleugh, H., Stafford Smith, M., Battaglia, M., Graham, P., Eds.; CSIRO Publishing: Collingwood, VIC, Australia, 2011.

49. Garnaut, R. Garnaut Climate Change Review Update 2011, Update Paper Four, Transforming Rural Land Use; Commonwealth of Australia: Canberra, ACT, Australia, 2011.

50. Kingwell, R. Climate change in Australia: Agricultural impacts and adaptation. Austr. Agribus. Rev. 2006, 14, Paper 1.

51. Qureshia, M.E.; Hanjrac, M.A.; Ward, J. Impact of water scarcity in Australia on global food security in an era of climate change. Food Policy 2013, 38, 136-145.

52. Beddington, J.; Asaduzzaman, M.; Clark, M.; Fernández, A.; Guillou, M.; Jahn, M.; Erda, L.; Mamo, T.; van Bo, N.; Nobre, C.A.; et al. Achieving Food Security in the Face of Climate Change: Final Report from the Commission on Sustainable Agriculture and Climate Change; CGIAR Research Program on Climate Change, Agriculture and Food Security (CCAFS): Copenhagen, Denmark, 2012.

53. AG. Australian National Greenhouse Accounts, National Inventory Report 2011 Volume 1, The Australian Government Submission to the United Nations Framework Convention on Climate Change April 2013; Department of Industry, Innovation, Climate Change, Science, Research and Tertiary Education: Canberra, ACT, Australia, 2013.

54. CoA. National Inventory by Economic Sector 2011-2012: Australia's National Greenhouse Accounts; Commonwealth of Australia: Canberra, ACT, Australia, 2014. 
55. Rickards, L.; Howden, S.M. Transformational adaptation: Agriculture and climate change. Crop Pasture Sci. 2012, 63, 240-250.

56. Carbon Farming. Available online: http://www.cleanenergyregulator.gov.au/Carbon-FarmingInitiative/Pages/default.aspx (accessed on 21 March 2015).

57. Emissions Reduction Fund. Available online: http://www.environment.gov.au/climatechange/emissions-reduction-fund (accessed on 20 March 2015).

58. Lam, S.K.; Chen, D.; Mosier, A.R.; Roush, R. The potential for carbon sequestration in Australian agricultural soils is technically and economically limited. Sci. Rep. 2013, 3, 2179.

59. Alexander, S. Peak Oil is Alive and Well, and Costing the Earth. The Conversation, 9 September 2013. Available online: http://theconversation.com/peak-oil-is-alive-and-well-and-costing-theearth-17542 (accessed on 5 October 2013).

60. Murray, J.W.; Hansen, J. Peak oil and energy independence: Myth and reality. Eos 2013, 94, $245-252$.

61. Pfeiffer, D.A. Eating Fossil Fuels: Oil, Food and the Coming Crisis in Agriculture; New Society Publishers: Gabriola Island, BC, Canada, 2006.

62. Australian Government. Water for the Future; Restoring the Balance in the Murray-Darling Basin; Australian Government: Canberra, ACT, Australia, 2010.

63. Stewart, W.M.; Dibb, D.W.; Johnston, A.E.; Smyth, T.J. The contribution of commercial fertilizer nutrients to food production. Agron. J. 2005, 97, 1-6.

64. Cordell, D.; Drangert, J.; White, S. The story of phosphorus: Global food security and food for thought. Glob. Environ. Chang. 2009, 19, 292-305.

65. Cordell, D.; Jackson, M.; White, S. Phosphorus flows through the Australian food system: Identifying intervention points as a roadmap to phosphorus security. Environ. Sci. Policy 2013, 29, 87-102.

66. Pratt, S. Future Fertilizer Supplies Expected to Send Prices Down. Available online: http://www.producer.com/2013/04/future-fertilizer-supplies-expected-to-send-prices-down/ (accessed on 3 October 2013).

67. Lawrence, D. Why Cheap Natural Gas May Be a Boost to Farmers. Available online: http://www.theglobeandmail.com/report-on-business/breakthrough/why-cheap-natural-gas-is-aboost-to-farmers/article14227180/ (accessed on 3 October 2013).

68. Buxton, M.; Alvarez, A.; Butt, A.; Farrell, S.; O’Neill, D. Planning Sustainable Futures for Melbourne's Peri-Urban Region; RMIT University: Melbourne, Australia, 2008.

69. Lloyd, D.J.; Luke, H.; Boyd, W.E. Community perspectives of natural resource extraction: Coal seam gas mining and social identity in South Eastern Australia. Coolabah 2013, 10, 144-164.

70. Department of Agriculture, Fisheries and Forests. Australian Food Statistics 2010-2011; Department of Agriculture Fisheries and Forests: Canberra, ACT, Australia, 2012.

71. National Farmers' Federation. NFF Farm Facts: 2012; National Farmers' Federation: Canberra, ACT, Australia, 2013.

72. Department of Agriculture, Fisheries and Forests. National Food Plan: Our Food Future; Department of Agriculture, Fisheries and Forests: Canberra, ACT, Australia, 2013.

73. Australian Government. Australia in the Asian Century, White Paper; Australian Government: Canberra, ACT, Australia, 2012. 
74. Department of Agriculture, Fisheries and Forests. National Food Plan Green Paper 2012; Department of Agriculture, Fisheries and Forestry: Canberra, ACT, Australia, 2012.

75. Abbott, T. The Coalition's 2030 Vision for Developing Northern Australia June 2013. Available online: http://www.tonyabbott.com.au/LinkClick.aspx?fileticket=ymP4ynYQKOA\%3D\&tabid= 86 (accessed on 29 August 2013).

76. Napthine, D. Growing Food Exports into Asia, Victoria Well Positioned to be Part of "Food Boom", Speech at the Global Food Forum. Available online: http://www.theaustralian.com.au/ business/in-depth/growing-food-exports-into-asia/story-fni2wt8c-1226623320373 (accessed on 26 August 2013).

77. Pratt, A. Australia, the "Clean Green Food Bowl of Asia", Keynote Speech at the Global Food Forum. Available online: http://www.theaustralian.com.au/business/in-depth/australia-the-cleangreen-food-bowl-of-asia/story-fni2wt8c-1226623265405 (accessed on 26 August 2013).

78. NALWTF. Northern Australia Land and Water Science Review 2009 Chapter Summaries; Northern Australian Land and Water Task Force; Department of Infrastructure; Transport; Regional Development and Local Government: Canberra, ACT, Australia, 2009.

79. Davidson, B. The Northern Myth: Limits to Agriculture and Pastoral Development in Tropical Australia, 3rd ed.; Melbourne University Press: Carlton, VIC, Australia, 1972.

80. Tilman, D.; Cassman, K.G.; Matson, P.A.; Naylor, R.; Polasky, S. Agricultural sustainability and intensive production practices. Nature 2002, 418, 671-677.

81. Patel, R. What does food sovereignty look like? J. Peasant Stud. 2009, 36, 663-706.

82. Menezes, F. Food sovereignty: A vital requirement for food security in the context of globalization. Development 2001, 44, 29-33.

83. Hamawand, I.; Yusaf, T.; Hamawand, S.G. Coal seam gas and associated water: A review paper. Renew. Sustain. Energy Rev. 2013, 22, 550-560.

84. Bark, R.; Kirby, M.; Connor, J.D.; Crossman, N.D. Water allocation reform to meet environmental uses while sustaining irrigation: A case study of the Murray-Darling Basin, Australia. Water Policy 2014, 16, 739-754.

85. Penney, A.; Kirby, D.; Cheshire, K.; Wilson, M.; Bray, S. Technical Review for the Commonwealth Policy on Fisheries Bycatch: Risk Based Approaches, Reference Points and Decision Rules for Bycatch and By-Product Species; Australian Bureau of Agricultural and Resource Economic; Department of Agriculture, Fisheries and Forests: Canberra, ACT, Australia, 2013.

86. Grech, A.; Bos, M.; Brodie, J.; Coles, R.; Dale, A.; Gilbert, R.; Hamann, M.; Marsh, H.; Neil, K.; Pressey, R.L.; et al. Guiding principles for the improved governance of port and shipping impacts in the Great Barrier Reef. Mar. Pollut. Bull. 2013, 75, 8-20.

87. Farmar-Bowers, Q.; Higgins, V.; Millar, J. Food Security in Australia: Challenges and Prospects for the Future; Farmar-Bowers, Q., Higgins, V., Millar, J., Eds.; Springer: New York, NY, USA, 2013.

88. Katz, D.L.; Meller, S. Can we say what diet is best for health? Annu. Rev. Public Health 2014, 35, 83-103.

89. NHMRC. Australian Dietary Guidelines. Available online: http://www.eatforhealth.gov.au/ sites/default/files/files/the_guidelines/n55_australian_dietary_guidelines.pdf (accessed on 20 March 2013). 
90. Meyer, S.B.; Coveney, J.; Henderson, J.; Ward, P.R.; Taylor, A.W. Reconnecting Australian consumers and producers: Identifying problems of distrust. Food Policy 2012, 37, 634-640.

91. Burdon, P. What is good land use? From rights to relationships. Melb. Univ. Law Rev. 2010, 34, 708-735.

92. Lawrence, G.; Richards, C.; Lyons, K. Food security in Australia in an era of neoliberalism, productivism and climate change. J. Rural Stud. 2013, 29, 30-39.

93. Selvey, L.A.; Carey, M.G. Australia's dietary guidelines and the environmental impact of food "from paddock to plate". Med. J. Aust. 2013, 198, 18-19.

94. Liu, Y.; Pan, X.; Li, J. Current agricultural practices threaten future global food production. J. Agric. Environ. Ethics 2015, 28, 203-216.

95. Biddle, N.; Bursian, O. FactCheck: Is Poverty on the Rise in Australia? Available online: $\mathrm{http}$ //theconversation.com/factcheck-is-poverty-on-the-rise-in-australia-17512 (accessed on 5 October 2013).

96. Bursian, O. We should be Shamed by Our Record on Child Poverty. Available online: http://theconversation.com/we-should-be-shamed-by-our-record-on-child-poverty-15698 (accessed on 5 October 2013).

97. Department of Agriculture, Fisheries and Forestry. Queensland's Agriculture Strategy: A 2040 Vision to Double Agricultural Production. Report CS2320, 06/13; Department of Agriculture, Fisheries and Forestry: Queensland, Australia, 2013.

98. Hannam, P. Tony Abbott's Government is "Recklessly Endangering" the Future on Climate, Says UK Chief. The Sydney Morning Herald 2014. Available online: http://www.smh.com.au/ federal-politics/political-news/tony-abbotts-government-is-recklessly-endangering-the-future-onclimate-says-uk-chief-20140708-zszx4.html (accessed on 20 February 2015).

99. International Covenant on Economic, Social and Cultural Rights. Available online: http://www.ohchr.org/EN/ProfessionalInterest/Pages/CESCR.aspx (accessed on 21 March 2015).

100. Roetter, R.P.; van Keulen, H. Food Security. In Science for Agriculture and Rural Development in Low-Income Countries; Roetter, R.P., van Keulen, H., Verhagan, J., Kuiper, M., Verhagen, J., van Laar, H.H., Eds.; Springer Science + Business Media B.V.: Dordrecht, The Netherlands, 2008; Chapter 3, pp. 27-56.

101. SIGNAL. Eat Well Australia, A Strategic Framework for public Health Nutrition, 2000-2010. Strategic Inter-Governmental Nutrition Alliance of the National Public Health Partnership 2001. Available online: http://www.health.vic.gov.au/archive/archive2014/nphp/ (accessed on 26 August 2013).

102. Neset, T.S.; Cordell, D. Global phosphorus scarcity: Identifying synergies for a sustainable future. J. Sci. Food Agric. 2012, 92, 2-6.

103. Lindenmayer, D.; Cunningham, S.; Young, A. Land Use Intensification: Effects on Agriculture, Biodiversity and Ecological Processes; Lindenmayer, D., Cunningham, S., Young, A., Eds.; CSIRO Publishing: Collingwood, VIC, Australia, 2012.

104. Steffen, W.; Richardson, K.; Rockström, J.; Cornell, S.E.; Fetzer, I.; Bennett, E.M.; Biggs, R.; Carpenter, S.R.; de Vries, W.; de Wit, C.A.; et al. Planetary boundaries: Guiding human development on a changing planet 2015. Science 2015, 347, doi:10.1126/science.1259855. 
105. Norton, D.; Reid, N. Nature and Farming: Sustaining Native Biodiversity in Agricultural Landscapes; CSIRO Publishing: Collingwood, VIC, Australia, 2013.

106. Gunn, I. Private Land is an Important Piece of the Conservation Jigsaw. Available online: http://theconversation.com/private-land-is-an-important-piece-of-the-conservation-jigsaw-11572 (accessed on 10 October 2013).

107. Stokes, C.J.; Howden, S.M. An Overview of Climate Change Adaptation in Australian Primary Industries-Impacts, Options and Priorities; CSIRO: Canberra, ACT, Australian, 2008.

108. Barlow, K.M.; Christy, B.P.; O’Leary, G.J.; Riffkin, P.A.; Nuttal, J.G. Simulating the impact of extreme heat and frost events on wheat crop production: A review. Field Crops Res. 2015, 171, $109-119$.

109. An Outline of Social Security. Available online: http://www.humanservices.gov.au/customer/ dhs/centrelink (accessed on 20 March 2015)

110. An Outline of Medicare Services. Available online: http://www.humanservices.gov.au/customer/ subjects/medicare-services (accessed on 21 March 2015).

111. An outline of Commonwealth Conservation Arrangements on Private Land. Available online: http://www.environment.gov.au/biodiversity/conservation/index.html\#private (accessed on 20 March 2015).

112. NRMMC. Australia's Biodiversity Conservation Strategy 2010-2030; Commonwealth of Australia: Canberra, ACT, Australia, 2010.

113. Ireland, J. Canberra Moves to Make People Wait a Week For Welfare. Available online: http://www.smh.com.au/federal-politics/political-news/canberra-moves-to-make-people-wait-aweek-for-welfare-20140520-38mnr.html (accessed 20 February 2015).

114. Australian Medical Association. Comments on Co-Payments. Available online: http://www.abc.net.au/news/2014-12-17/gp-co-payment-opposed-by-australian-medicalassociation/5974342 (accessed on 20 March 2015).

115. A political View of the Abbot's Government's Actions on Climate Change. Available online: http://larissa-waters.greensmps.org.au/abbotts-attacks-environment (accessed on 21 March 2015).

116. George, S. A Short History of Neo-liberalism: Twenty Years of Elite Economics and Emerging Opportunities for Structural Change. In Proceedings of the Conference on Economic Sovereignty in a Globalising World, Bangkok, Thailand, 24-26 March 1999.

117. Harvey, D. A Brief History of Neoliberalism; Oxford University Press: Oxford, UK, 2005.

118. Lansley, S. Inequality, the crash and the ongoing crisis. Political Quart. 2012, 83, 754-761.

119. APS. Submission to the Senate Community Affairs References Committee Inquiry into the Extent of Income Inequality in Australia; Australian Psychological Society: Melbourne, VIC, Australia, 2014.

120. Wilkinson, R.G.; Pickett, K. The Spirit Level: Why More Equal Societies Almost Always Do Better; Allen Lane: London, UK, 2009.

121. Whiteford, P. Australia: Inequality and Prosperity and Their Impacts in a Radical Welfare State. Social Policy Action Research Centre, Crawford School of Public Policy, the Australian National University 2013. Available online: https://crawford.anu.edu.au/public_policy_community/content/ doc/Australia_Inequality-and-Prosperity_final-15-March-13.pdf (accessed on 3 October 2013). 
122. NSC. Sustainable Australia Report 2013, Conversation with the Future-In Brief. National Sustainability Council, Australian Government 2013. Available online: http://www.environment. gov.au/system/files/resources/e55f5f00-b5ed-4a77-b977-da3764da72e3/files/sustainableaustralia-report-2013-summary.pdf (accessed on 23 March 2015).

123. OECD. Divided We Stand: Why Inequality Keeps Rising; OECD Publishing: Paris, France, 2011.

124. Primrose, D. Contesting capitalism in the light of the crisis: A conversation with David Harvey. J. Aust. Political Econ. 2013, 71, 5-25.

125. The Australian Greens Policy on Sustainable Agriculture. Available online: http://greens.org.au/ policies/sustainable-agriculture (accessed on 20 March 2015).

126. CoD. Food Security Policy, City of Darebin, Victoria, Australia 2010. Available online: http://www.darebin.vic.gov.au/ /media/cityofdarebin/Files/Darebin-Living/CaringfortheEnviron ment/SustainableLiving/Food-Security-Policy-Final.ashx?la=en (accessed on 25 February 2015).

127. Commonwealth of Australia. Agricultural Competitiveness Green Paper; Commonwealth of Australia: Canberra, ACT, Australia, 2014.

128. Economist Intelligence Unit. The Global Food Security Index. Available online: http://foodsecurityindex.eiu.com (accessed on 22 March 2015).

129. Locke, E.A.; Latham, G.P. Building a practically useful theory of goal setting and task motivation: A 35-year odyssey. Am. Psychol. 2002, 57, 705-717.

130. AHRC Webpage. Australian Human Rights Commission. Available online: https://www.humanrights.gov.au/ (accessed on 21 May 2015).

131. AG. Australia's National Human Rights Action Plan 2012. Available online: http://www.ag.gov.au/Consultations/Documents/NationalHumanRightsActionPlan/National\%20 Human\%20Rights\%20Plan.pdf (accessed on 10 October 2013).

132. Tasmanian Food Security Council. Food for All Tasmanians: A Food Security Strategy (2012). Available online: http://www.dpac.tas.gov.au/_data/assets/pdf_file/0005/159476/Food_for_all_ Tasmanians_-_A_food_Security_Strategy.PDF (accessed on 8 October 2012).

133. Rudd, K. House of Representatives National Security Speech. Available online: http://parlinfo. aph.gov.au/parlInfo/genpdf/chamber/hansardr/2008-12-04/0045/hansard_frag.pdf;fileType= application\%2Fpdf (accessed on 26 March 2012).

134. AG. Critical Infrastructure Resilience Strategy. Available online: http://www.tisn.gov.au/ Documents/Australian+Government $+\mathrm{s}+$ Critical+Infrastructure + Resilience + Strategy.pdf (accessed on 1 October 2013).

135. WCED. Our Common Future (Brundtland Report); United Nations World Commission on Environment and Development; Oxford University Press: Oxford, UK, 1987.

136. Max-Neef, M. With Contributions from Antonio Elizalde and Martin Hopenhayn. Human Scale Development Conception, Application and Further Reflections; The Apex Press: New York, NY, USA; London, UK, 2012.

137. Deci, E.L.; Ryan, R.M. The Darker and Brighter Side of Human Existence: Basic Psychological Needs as a Unifying Concept. Psychol. Inq. 2000, 11, 319-338.

138. Ryan, R.M.; Deci, E.L. Self-determination theory and the facilitation of intrinsic motivation, social development, and well-being. Ame. Psychol. 2000, 55, 68-78.

139. Sumner, L.W. Welfare, Happiness and Ethics; Clarendon Press: Oxford, UK, 1996. 
140. Haybron, D.M. The Pursuit of Unhappiness, the Elusive Psychology of Well-Being; Oxford University Press: Oxford, UK; New York, NY, USA, 2008.

141. Helliwell, J.; Layard, R.; Sachs, J. World Happiness Report 2013. Available online: http://unsdsn.org/wp-content/uploads/2014/02/WorldHappinessReport2013_online.pdf (accessed on 20 May 2015)

142. Nussbaum, M.C. Capabilities, entitlements, rights: Supplementation and critique. J. Hum. Dev. Capab. 2011, 12, 23-37.

143. Nussbaum, M.C. Women and Human Development: The Capabilities Approach; Cambridge University Press: Cambridge, UK, 2000.

144. Sen, A. The ends and means of sustainability. J. Hum. Dev. Capab. 2013, 14, 6-20.

145. Farmar-Bowers, Q. Making Sustainable Development Ideas Operational: A General Technique for Policy Development; VDM Verlag Dr. Müller: Saarbrücken, Germany, 2008.

146. Pelenc, J.; Lompo, M.K.; Ballet, J.; Dubois, J. Sustainable human development and the capability approach: Integrating environment, responsibility and collective agency. J. Hum. Dev. Capab. 2013, 14, 77-94.

147. Leopold, A. The Land Ethic. pp. 87-100 in Environmental Philosophy, From Animal Rights to Radical Ecology, 2nd ed.; Zimmerman, M.E., Ed.; Prentice Hall: Upper Saddle River, NJ, USA, 1998.

148. McLaughlin, A. Regarding Nature; State University of New York Press: New York, NY, USA, 1993.

149. The Foundation for Deep Ecology. Available online: http://www.deepecology.org/platform.htm (accessed on 21 March 2015).

150. Devall, W.; Sessions, G. Deep Ecology: Living as if Nature Mattered; Peregrine Smith: Salt Lake City, UT, USA, 1985.

151. Meyer, J.L. The State of the Global Environment. pp. 7-15 in Ethics and the Global Marketplace; Dallmeyer, D.G., Ike, A.F., Eds.; The University of Georgia Press: London, UK, 1998.

152. Fieldman, G. Neoliberalism, the production of vulnerability and the hobbled state: Systematic barriers to climate adaptation. Clim. Dev. 2011, 3, 159-174.

153. Ericksen, P.J. What is the vulnerability of a food system to global environmental change? Ecol. Soc. 2008, 13, 14.

154. Gunasekera, D.; Newth, D.; Finnigan, J. Reconciling the competing demands in the Human-Earth system: Ensuring food security. Econ. Papers 2011, 30, 296-306.

155. Resilience Alliance. Assessing Resilience in Social-Ecological Systems: Workbook for Practitioners, Version 2.0, 2010. Available online: http://www.resalliance.org/3871.php (accessed on 26 March 2012).

156. Walker, B.; Salt, D. Resilience Thinking, Sustaining Ecosystems and People in a Changing World; Island Press: Washington, DC, USA, 2006

157. Anderies, J.M.; Folke, C.; Walker, B.; Ostrom, E. Aligning key concepts for global change policy: Robustness, resilience, and sustainability. Ecol. Soc. 2013, 18, 8.

158. Meadows, D. Leverage Points Places to Intervene in a System; The Sustainability Institute: Hartland, VT, USA, 1999. 
159. Marsden, J. Fossil Fuel Industry's Tired Battle against Clean Energy Is Also a Losing One. Available online: http://www.forbes.com/sites/edfenergyexchange/2014/04/12/fossil-fuelindustrys-tired-battle-against-clean-energy-is-also-a-losing-one/ (accessed on 21 March 2015).

160. IRENA. Renewable Power Generation Costs in 2014. Available online: http://www.irena.org/ DocumentDownloads/Publications/IRENA_RE_Power_Costs_2014_report.pdf (accessed on 20 February 2015).

161. Parkinson, G. Fossil Fuels Win Battle over RET, but Will They Win the War? Available online: http://reneweconomy.com.au/2014/fossil-fuels-win-battle-over-ret-but-will-they-win-the-war60416 (accessed on 20 February 2015).

162. Readfearn, G. Gods and Faith versus Coal in Name of Climate Change. Available online: http://www.theguardian.com/environment/planet-oz/2014/dec/05/gods-and-faith-versus-coal-inname-of-climate-change (accessed on 20 February 2015).

163. Weaver-Hightower, M.B. Why education researchers should take school food seriously. Educ. Res. 2011, 40, 15-21.

164. Arup, T. Abbott Shuts Down Climate Commission, 19 September 2013, Sydney Morning Herald. Available online: http://www.smh.com.au/federal-politics/political-news/abbott-shuts-downclimate-commission-20130919-2u185.html (accessed on 26 February 2015).

165. White, A. Climate change "off the G20 agenda" as Australia Prepares to Abolish the Carbon Price. Available online: http://www.theguardian.com/environment/southern-crossroads/2014/jun/05/ g20-climate-change-agenda-obama-abbott (accessed on 26 February 2015).

(C) 2015 by the authors; licensee MDPI, Basel, Switzerland. This article is an open access article distributed under the terms and conditions of the Creative Commons Attribution license (http://creativecommons.org/licenses/by/4.0/). 